\title{
Integrating the evidence: confronting the COVID-19 elephant
}

\author{
John J. Marini ${ }^{*}$ (I), R. Phillip Dellinger ${ }^{2}$ and Daniel Brodie ${ }^{3}$
}

(c) 2020 Springer-Verlag GmbH Germany, part of Springer Nature

Coronavirus disease 2019 (COVID-19) is an unfamiliar illness with potentially devastating consequences. The pandemic is unfolding at different rates with wide geographic separation and seemingly erratic expression. There is well-justified urgency to describe the inconsistently expressed features of this new viral disease and implement strategies to avoid and treat it [1-4].

Because COVID-19-related illness is caused by a single virus, it seems reasonable to assume a degree of uniformity across populations. Yet, some observations are universal while others apparently conflict. In this urgent situation, we feel impelled to skip steps in the traditional methodology of first making careful observations and then conducting evidence-building research to inform rational management. We have been down this road before of needing to act while not fully understanding a new pathogen variant. But this SARS-CoV-2/COVID-19 seems different. This time around, the disease may infect anyone and most organ systems and is readily and rapidly transmitted. We have a right to be frightened of this novel virus.

Mastering the entirety of medicine is impossible; practicing doctors are trained to diagnose (label) by interpreting observations using their prior education and experience, and then manage on that basis. We have a natural tendency to 'force-fit' newly encountered fragments of unfamiliar information into our existing constructs and understandings. (In psychology, this is known as the Barnum effect [5].) Although usually a functional approach to decision-making when dealing with too little information, we may unintentionally make errors

*Correspondence: marin002@umn.edu

${ }^{1}$ Departments of Pulmonary and Critical Care Medicine, Regions Hospital and University of Minnesota, Minneapolis/St. Paul, MN, USA

Full author information is available at the end of the article when the disease seems as alien and multifaceted as COVID-19.

The acute respiratory distress syndrome (ARDS) that figures so prominently in severe cases of COVID infection may seem familiar but has historically predisposed to such logical missteps [6]. ARDS itself was originally perceived as a high permeability edema and low lung compliance condition that disrupted function of all alveolar units and resulted primarily from surfactant deficiency [7]. Cause and histologic manifestations went hand-inhand. This simple perception provided for adult patients a convenient explanation that paralleled that of the infant respiratory distress syndrome, a condition for which the root cause mechanism had already been confirmed [8]. Indeed, for some years after its initial description, the designation of 'Adult Respiratory Distress' reflected this flawed theory of cause and effect.

More recently, considerations of lung compliance and underlying pathology have yielded to a broader definition of ARDS based on a relatively acute onset of a known precipitant that impairs oxygenation and produces otherwise unexplained multi-lobar infiltrates [9]. Airspace flooding, collapse, and consolidation are envisioned to parallel (more or less) the severity of oxygenation impairment $[9,10]$. Most often, this view serves reasonably well. As pathologic severity increases, key definitional features of ARDS (extensive infiltrates, hypoxemia) usually proceed in synch, serving to guide clinical treatment and prognosis by gas exchange criteria. Accordingly, choices for positive end-expiratory pressure (PEEP), tidal volume, and prone positioning are made with the intention of improving oxygenation and recruiting lung units while avoiding ventilator-induced lung injury (VILI). Clinical trials and guideline tables for mechanical ventilation in ARDS are, for better or worse, keyed to the severity of oxygenation deficit [11]. At the bedside, VILI risk is

\section{Springer}


indexed by plateau pressure, driving pressure, and more recently by mechanical power [12].

Certain features of COVID-19-associated ARDS (what has been termed "CARDS") seem to challenge that useful conceptual framework. Specifically, lung compliance may be well preserved in the early and mild stages of CARDS (at least in a subpopulation of these patients), because severe hypoxemia may not originate at first primarily from airspace filling and lung unit drop-out-though these do occur to some modest extent-but rather from a microvascular attack that dysregulates ventilation/perfusion matching in well-ventilated lung units and increases dead space [13]. When simpler measures fail, the familiar initial response is to improve oxygenation-use higher PEEP and lower tidal volumes, offsetting any hemodynamic consequences. Yet, it stands to reason (though still unproven) that because these lungs are initially gas filled and unexpectedly flexible for the severity of hypoxemia, such actions might needlessly accentuate the underlying problem and increase iatrogenic risk without proportionate benefit $[13,14]$. In more severe cases and at a later stage, however, those same actions become quite appropriate. In summary, it is not yet known whether standard evidence-based approaches to ARDS management apply equally well at all stages and severities of CARDS. Progress in understanding the biological mechanisms of
COVID-19 has been quite rapid, but there remain many unknowns regarding its expression and management.

In confronting COVID-19, there have been shared experiences and points of agreement (Table 1), but the varied and puzzling expressions of COVID-19 have challenged the uniformity of our perceptions and in some cases stimulated brisk controversy [15-18]. For example, we argue: Does intense, sepsis-like cytokine release drive shock? [15]. Should we manage CARDS as routine ARDS? [18]. The basis of such disagreements may lie less with the soundness of the observations among reports and more with patient vulnerability to attack by COVID-19 and its rapidly evolving pathophysiology. The validity of any given observation and inference for management may depend strongly, for instance, on when in the course of the encounter the observation was made (Fig. 1).

In a sense, with COVID-19, we intensivists are like the blind people of an ancient Indian parable who stumble upon an unfamiliar animal, an elephant. Each individual forms a different image of the unseen beast from the part his or her own hands happen to fall upon that resembles the familiar. The individual tactile sensations are undeniable, and each interpretation and extrapolation to characterize the elephant is understandable-but ultimately, incomplete.

\section{Table 1 Coronavirus features: uncontested and contested}

\begin{tabular}{|c|c|}
\hline Shared observations and uncontested features ${ }^{a}$ & Puzzling or contested features ${ }^{a}$ \\
\hline The virus is easily spread and by multiple routes (droplet, aerosol, contact) & What explains striking geographic differences of incidence? \\
\hline $\begin{array}{l}\text { Many infected persons are asymptomatic, a smaller number require hospi- } \\
\text { talization, and even fewer develop respiratory failure }\end{array}$ & What explains highly variable mortality rates, site-to-site? \\
\hline $\begin{array}{l}\text { Children are affected less often and usually less severely than adults, yet } \\
\text { may have rare post-infectious complications related to previous vascular } \\
\text { invasion }\end{array}$ & $\begin{array}{l}\text { Are there different COVID-19 genetic types and virulence, perhaps due to } \\
\text { its RNA mutations? }\end{array}$ \\
\hline $\begin{array}{l}\text { Mortality rates are higher among those with diabetes, hypertension, } \\
\text { chronic heart or lung disease, the elderly, and the morbidly obese }\end{array}$ & $\begin{array}{l}\text { Can we develop an effective vaccine against variants of COVID and dis- } \\
\text { tribute it worldwide? How long will such a vaccine be effective? }\end{array}$ \\
\hline So-called 'silent hypoxemia' may precede overt respiratory distress & Are there inflammatory versus non-inflammatory phenotypes of CARDS? \\
\hline $\begin{array}{l}\text { Unusually high minute ventilation and high dead space may be evident } \\
\text { from the outset }\end{array}$ & $\begin{array}{l}\text { What role does 'cytokine storm' play in the clinical presentations of COVID- } \\
19 \text { ? }\end{array}$ \\
\hline Abrupt deterioration often occurs after days of smoldering infection & $\begin{array}{l}\text { Do symptomatic patients who present with severe hypoxemia sort into "L } \\
\text { and } \mathrm{H}^{\prime \prime} \text { phenotypes? }\end{array}$ \\
\hline $\begin{array}{l}\text { Respiratory system compliance is not invariably low in the presence of } \\
\text { severe hypoxemia }\end{array}$ & $\begin{array}{l}\text { Do patients progress to diffuse airspace disease via patient self-inflicted } \\
\text { lung injury (PSILI)? }\end{array}$ \\
\hline $\begin{array}{l}\text { Incidence of blood clotting appears to be high in hospitalized COVID-19 } \\
\text { patients }\end{array}$ & $\begin{array}{l}\text { Does the fact that CARDS patients meet the Berlin definition mean that } \\
\text { these patients will respond to standard approaches and guidelines for } \\
\text { ARDS? }\end{array}$ \\
\hline $\begin{array}{l}\text { Early CT infiltrates occurring in severely hypoxemic patients are often scant, } \\
\text { peripheral, and characterized by atypical 'ground glass' or 'crazy paving' }\end{array}$ & $\begin{array}{l}\text { Does disrupted vasoregulation with minor shunt explain the severity of } \\
\text { early hypoxemia? }\end{array}$ \\
\hline Prone positioning and PEEP improve $\mathrm{PaO}_{2} / \mathrm{FiO}_{2}$ & Should full anticoagulation be routinely implemented? \\
\hline $\begin{array}{l}\text { Respiratory failure often resolves slowly in the most severely ill who do } \\
\text { survive }\end{array}$ & $\begin{array}{l}\text { Which available drugs and proposed anti-viral approaches for COVID-19 } \\
\text { treatment hold the most potential for benefit or risk? }\end{array}$ \\
\hline
\end{tabular}




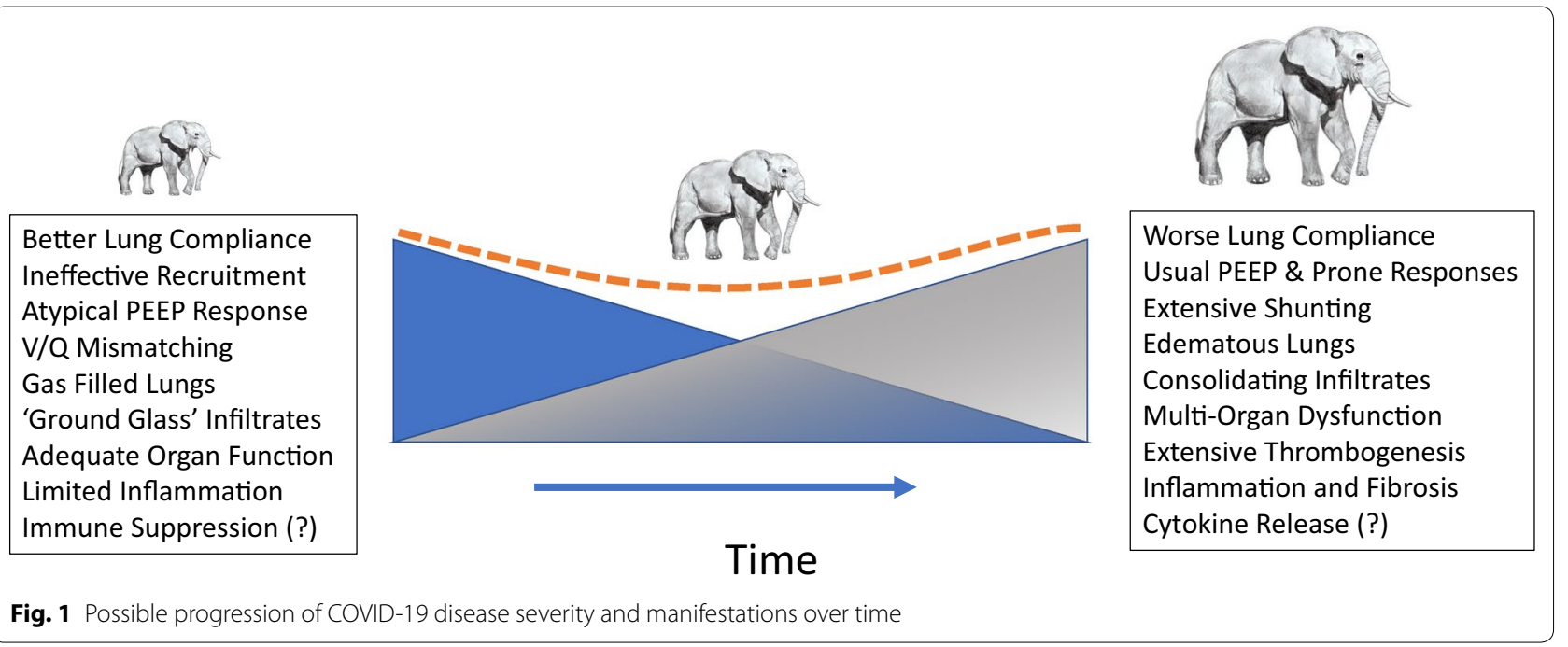

So it may be with COVID-19. Well-meaning authors may advocate for individual interpretations, but our current views of the entire problem are obscured and our answers half-finished. Although pathogenesis is becoming progressively clear and many clinical trials of promising treatments and vaccines have been initiated, we are still at the stage of gathering fundamental observations from which a unified theory of pathogenesis might be constructed, and around which logical and effective treatment approaches might coalesce. The scientific process is self-correcting; over time, varied high-quality scientific and clinical observations will eventually be drawn together into a coherent, unified entity. Although urgency demands that we test especially promising and logical treatment options, for the present time, it seems prudent for the medical community to collate valid observations and experiences from all quarters, form the right image of a dynamic entity, and then devise an appropriate strategy to modify supportive care as we proceed to develop effective countermeasures. As the Rajah said to the bickering blind men when advising them to humbly reflect before drawing conclusions: "The elephant is a very large and rather strange animal. Each man touched only one part. Perhaps if you put the parts together, you will eventually see the truth."

\footnotetext{
Author details

${ }^{1}$ Departments of Pulmonary and Critical Care Medicine, Regions Hospital and University of Minnesota, Minneapolis/St. Paul, MN, USA. ${ }^{2}$ Cooper Medical School of Rowan University, Camden, NJ, USA. ${ }^{3}$ Division of Pulmonary, Allergy and Critical Care Medicine, Columbia University College of Physicians and Surgeons/New York-Presbyterian Hospital, New York, NY, USA.
}

Compliance with ethical standards

\section{Conflicts of interest}

Dr. Brodie receives research support from ALung Technologies; he was previously on their medical advisory board. He has been on the medical advisory boards for Baxter, BREETHE, Xenios and Hemovent. JJM and RPD report no conflicts of interest.

\section{Publisher's Note}

Springer Nature remains neutral with regard to jurisdictional claims in published maps and institutional affiliations.

Received: 5 July 2020 Accepted: 20 July 2020

Published online: 25 July 2020

\section{References}

1. Waterer GW, Rello J, Wunderink RG (2020) SARS-CoV-2: first do no harm. Am J Respir Crit Care Med. https://doi.org/10.1164/rccm.202004-1153ED

2. Morse JS, Lalonde T, Xu S et al (2020) Learning from the past: possible urgent prevention and treatment options for severe acute respiratory infections caused by 2019-nCoV. ChemBioChem 21(5):730-738. https:// doi.org/10.1002/cbic.202000047

3. Wang Y, Zhang D, Du G et al (2020) Remdesivir in adults with severe COVID-19: a randomised, double-blind, placebo-controlled, multicentre trial. Lancet 395:1569-1578

4. Chen L, Xiong J, Bao L et al (2020) Convalescent plasma as a potential therapy for COVID-19. Lancet Infect Dis 20(4):398-400

5. Johnson JT, Cain LM, Falk TL, Hayman J, Perillo E (1985) The, "Barnum effect" revisited: cognitive and motivational factors in the acceptance of personality descriptions. J Pers Soc Psychol 49:1378-1391

6. Gattinoni L, Coppola S, Cressoni M, Busana M, Chiumello D (2020) Covid-19 does not lead to a "typical" acute respiratory distress syndrome. Am J Respir Crit Care Med 201(10):1299-1300. https://doi.org/10.1164/ rccm.202003-0817LE

7. Ashbaugh DG, Bigelow DB, Petty TL, Levine BE (1967) Acute respiratory distress in adults. Lancet 2(7511):319-323. https://doi.org/10.1016/s0140 -6736(67)90168-7

8. Farrell PM, Avery ME (1975) Hyaline membrane disease. Am Rev Respir Dis 111(5):657-688. https://doi.org/10.1164/arrd.1975.111.5.657

9. Force ADT, Ranieri VM, Rubenfeld GD, Thompson BT, Ferguson ND, Caldwell E et al (2012) Acute respiratory distress syndrome: the Berlin Definition. JAMA 307(23):2526-2533 
10. Maiolo G, Collino F, Vasques F et al (2018) Reclassifying acute respiratory distress syndrome. Am J Respir Crit Care Med 197(12):1586-1595. https:// doi.org/10.1164/rccm.201709-1804OC

11. Kallet RH, Branson RD (2007) Do the NIH ARDS Clinical Trials network $\mathrm{PEEP} / \mathrm{FiO}_{2}$ tables provide the best evidence-based guide to balancing PEEP and $\mathrm{FiO}_{2}$ settings in adults? Respir Care 52(4):461-475

12. Marini JJ, Rocco PRM, Gattinoni L (2020) Static and dynamic contributors to ventilator-induced lung injury in clinical practice. Pressure, energy, and power. Am J Respir Crit Care Med 201(7):767-774. https://doi. org/10.1164/rccm.201908-1545ci

13. Marini JJ, Gattinoni L (2020) Management of Covid-19 respiratory distress. JAMA. https://doi.org/10.1001/jama.2020.6825

14. Mauri T, Spinelli E, Scotti E, Colussi G, Basile MC, Crotti S et al (2020) Potential for lung recruitment and ventilation-perfusion mismatch in patients with the acute respiratory distress syndrome from coronavirus disease 2019. Crit Care Med. https://doi.org/10.1097/CCM.0000000000004386
15. Leisman DE, Deutschman CS, Legrand M (2020) Facing COVID-19 in the ICU: vascular dysfunction, thrombosis, and dysregulated inflammation. Intensive Care Med 46:1105-1108. https://doi.org/10.1007/s00134-02006059-6

16. London AJ, Kimmelman J (2020) Against pandemic research exceptionalism. Science 368(6490):476-477. https://doi.org/10.1126/science.abc1731

17. Bos LDJ, Sinha P, Dickson RP (2020) The perils of premature phenotyping in COVID: a call for caution. Eur Respir J 56:2001768. https://doi. org/10.1183/13993003.01768-2020

18. Gattinoni L, Chiumello D, Caironi P, Busana M, Romitti F, Brazzi L, Camporota L (2020) COVID-19 pneumonia: different respiratory treatments for different phenotypes? Intensive Care Med. https://doi.org/10.1007/s0013 4-020-06033-2 